\title{
EFEKTIVITAS PENEGAKAN HUKUM DI BIDANG KEKAYAAN INTELEKTUAL OLEH PENYIDIK PEGAWAI NEGERI SIPIL*
}

\author{
Harison Citrawan $^{* *}$ dan Achmad Fikri Rasyidi ${ }^{* * *}$
}

\author{
Badan Penelitian dan Pengembangan Hukum dan Hak Asasi Manusia, \\ Kementerian Hukum dan Hak Asasi Manusia \\ J1. HR Rasuna Said Kav. 4-5 Kuningan Jakarta Selatan 12940
}

\begin{abstract}
This study attempts to analyse the effectiveness of intellectual property law enforcement by civil servant investigator. By applying the psychological type of the cognitive function, this study finds that: first, internally the civil servant investigator has in principal conducted their normative duties, although it yet to be ideal. Several internal factors that affect such a situation covering: (i) there is yet an organizing structure of IP investigator at the Law and Human Rights Regional Offices; and (ii) mismanagement in managing and positioning the investigators, as some are currently working in units outside the investigations duty. Second, externally based on normative review, it could be understood that IP law enforcement could be pursued through various mechanisms. In this context, the law has yet to endow the civil servant investigator an authority to get involved in penal mediation, which by and large delimits their ability in enforcing the law. Keywords: effectiveness, intellectual property, investigation.
\end{abstract}

\section{Intisari}

Kajian ini mencoba menggambarkan efektivitas penegakan hukum oleh PPNS di bidang kekayaan intelektual (KI). Dengan menggunakan psychological type of the cognitive function, ditemukan bahwa: Pertama, secara internal PPNS KI (KI) sudah menjalankan tugas dan fungsi PPNS KI, meskipun belum pada level ideal. Faktor-faktor internal yang memengaruhi hal tersebut yakni: (i) belum terdapat struktur PPNS KI di Kantor Wilayah Hukum dan HAM, dan (ii) penempatan PPNS ke dalam jabatan atau posisi tertentu yang tidak relevan dengan tugas dan wewenang PPNS. Kedua, secara eksternal berdasarkan tinjauan normatif, dipahami bahwa penegakan hukum KI dapat menempuh beberapa jalur. Adapun normativitas kewenangan PPNS yang tidak mencakup ranah mediasi penal justru menyebabkan kewenangan mereka menjadi sangat terbatas.

Kata Kunci: Efektivitas, Kekayaan Intelektual, Penyidikan.

\section{Pokok Muatan}

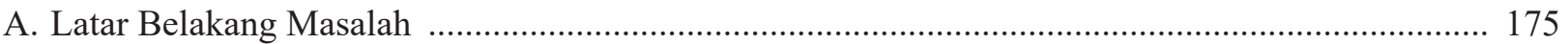

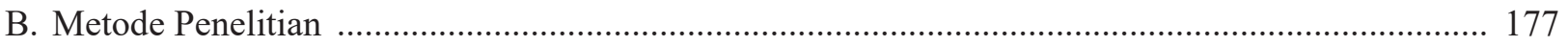

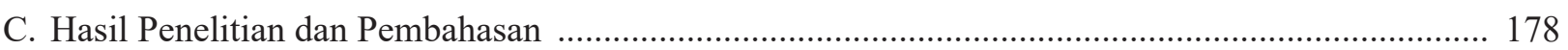

1. Mekanisme Penegakan Hukum Kekayaan Intelektual ................................................................. 178

2. Posisi PPNS dalam Penegakan Hukum Kekayaan Intelektual .................................................. 180

3. Efektivitas Penegakan Hukum Kekayaan Intelektual oleh PPNS ............................................. 181

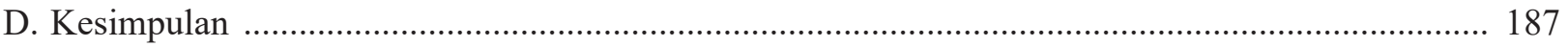

Penelitian ini merupakan kajian isu aktual yang didanai dan disupervisi oleh Badan Penelitian dan Pengembangan Hukum dan HAM pada tahun 2017. Para penulis secara khusus mengucapkan terima kasih kepada Yasmon, MLS sebagai Kepala Pusjianbang (periode 2017); segenap jajaran Direktorat Penyidikan dan Penyelesaian Sengketa, Direktorat Jenderal Kekayaan Intelektual; dan dua reviewer anonim atas kritik dan saran terhadap substansi penelitian ini.

** Alamat korespondensi: harison.citrawan@kemenkumham.go.id

*** Alamat korespondensi: achmad.fikri92@gmail.com. 


\section{A. Latar Belakang Masalah}

Penegakan hukum merupakan salah satu indikator penting dalam perlindungan kekayaan intelektual di Indonesia. Secara normatif, pelanggaran hukum atas kekayaan intelektual dapat dikategorikan sebagai sengketa keperdataan dan pidana yang centang-perenang diatur dalam beberapa undang-undang, meliputi: UU No. 28 Tahun 2014 tentang Hak Cipta, UU No. 13 Tahun 2016 tentang Paten, UU Nomor 20 Tahun 2016 tentang Merek dan Indikasi Geografis, UU No. 31 Tahun 2000 tentang Desain Industri, UU No. 32 Tahun 2000 tentang Desain Tata Letak Sirkuit Terpadu, UU No. 30 Tahun 2000 tentang Rahasia Dagang. Ketentuan pidana yang diatur sebagai hukum materiil, maka penegakan hukum dilakukan melalui mekanisme KUHAP sebagai hukum formil.

Berdasarkan penelusuran awal pada direktori putusan Mahkamah Agung, perkara pelanggaran hukum kekayaan intelektual yang diproses oleh pengadilan jauh lebih banyak berada pada area perdata daripada pidana. ${ }^{1}$ Rendahnya angka kasus pelanggaran kekayaan intelektual yang diproses melalui proses peradilan pidana menunjukkan beberapa fenomena kausal, yang meliputi: rendahnya kesadaran pemegang kekayaan intelektual terdaftar atas mekanisme penegakan hukum, mayoritas tindak pidana di bidang kekayaan intelektual merupakan delik aduan, tingkat pemahaman aparat penyidik kepolisian tentang rezim hukum kekayaan intelektual, dan belum optimalnya pendayagunaan penyidik pegawai negeri sipil di bidang kekayaan intelektual.

Patut disadari bahwa berdasarkan norma yang berlaku, jalur penyelesaian secara pidana di sektor kekayaan intelektual merupakan ultimum remedium. Hal ini mengisyaratkan bahwa tugas-tugas penegakan hukum pidana kekayaan intelektual, secara khusus penyidikan, berfungsi sebagai mekanisme terakhir dalam menyelesaikan sengketa. Berdasarkan konsep tersebut, dan mengingat sifat alami (nature) dari hukum perlindungan kekayaan intelektual, maka upaya koersif negara terhadap pelanggar hukum kekayaan intelektual tidak berjalan sebagaimana penegakan hukum pidana pada umumnya. ${ }^{2}$ Walaupun bekerja dalam kerangka konsep ultimum remedium tersebut, penulis berpendapat bahwa ketersediaan penyidik pegawai negeri sipil yang mumpuni tetap menjadi penting dalam melaksanakan regulasi.

Konteks tugas pokok dan fungsi Kementerian Hukum dan HAM dalam penegakan tindak pidana kekayaan intelektual sesungguhnya telah didukung oleh eksistensi perangkat norma, kelembagaan, serta sumber daya manusia. Ketiga perangkat tersebut bernaung di bawah kendali Direktorat Jenderal Kekayaan Intelektual yang bertugas "menyelenggarakan perumusan dan pelaksanaan kebijakan di bidang kekayaan intelektual." 3 Secara kelembagaan, dalam konteks penegakan hukum Direktorat Jenderal Kekayaan Intelektual memiliki Direktorat Penyidikan dan Penyelesaian Sengketa yang menjadi pelaksana kebijakan "di bidang penyidikan, pencegahan, penyelesaian sengketa dan evaluasi tindak pidana kekayaan intelektual". ${ }^{4}$

Lebih jauh, dari sisi sumber daya manusia, berdasarkan mandat undang-undang di sektor kekayaan intelektual, selain pejabat penyidik Kepolisian Negara Republik Indonesia, pejabat penyidik pegawai negeri sipil tertentu di lingkungan kementerian yang menyelenggarakan urusan pemerintahan di bidang hukum diberi wewenang khusus sebagai penyidik tindak pidana/pelanggaran di bidang kekayaan intelektual. ${ }^{5}$ Saat ini sudah

Berdasarkan jumlah rekapitulasi pada laman Direktori Putusan Mahkamah Agung, per 2018 sebagai berikut: Kasus Perdata Khusus Hak Cipta (69 kasus), Merek (414 kasus), Desain Industri (49 kasus), dan Paten (20 kasus). Sedangkan pidana kekayaan intelektual sebagai berikut: Hak Cipta (7 kasus), Paten (1 kasus).

Lihat Christoper Buccafusco dan Jonathan S. Masur, et al., "Innovation and Incarceration: An Economic Analysis of Criminal Intellectual Property Law", Southern California Law Review 87 (2014), 2014 hlm. 275-334. Irina D. Manta, "The Puzzle Sanctions for Intellectual Property Infringement", Harvard Journal of Law \& Technology, Vol. 24 No. 2 Spring 2011, hlm. 469-517.

Pasal 690 Peraturan Menteri Hukum dan HAM Nomor 29 Tahun 2015 tentang Organisasi dan Tata Kerja Kementerian Hukum dan HAM. Pasal 817 Peraturan Menteri Hukum dan HAM Nomor 29 Tahun 2015 tentang Organisasi dan Tata Kerja Kementerian Hukum dan HAM. Lihat Pasal 6 KUHAP. Lebih jauh, berdasarkan Penjelasan Pasal 3 Ayat (1) UU Kepolisian, yang dimaksud dengan 'dibantu' ialah dalam lingkup fungsi kepolisian, bersifat bantuan fungsional dan tidak bersifat struktural hierarkis. 
terdapat 143 pejabat penyidik pegawai negeri sipil kekayaan intelektual yang berada di bawah naungan Kementerian Hukum dan HAM, yang tersebar baik di Direktorat Jenderal Kekayaan Intelektual maupun di seluruh Kantor Wilayah.

Langkah-langkah progresif sesungguhnya telah diupayakan pemerintah, seperti pembentukan Tim Nasional Penanggulangan Pelanggaran Hukum Kekayaan Intelektual pada Tahun 2006. Selain itu, secara historis pembentukan Direktorat Penyidikan dan Penyelesaian Sengketa pada 2008 merupakan kebijakan yang diharapkan dapat mendorong efektivitas penegakan hukum kekayaan intelektual. Sedangkan dari sisi manajemen PPNS KI , Menteri Hukum dan HAM telah menerbitkan Keputusan No. M.HH-01.H1.07.02 Tahun 2015 tentang Petunjuk
Pelaksanaan Manajemen Penyidikan Tindak Pidana di Bidang Kekayaan Intelektual. Melalui keputusan ini, diharapkan PPNS memiliki pedoman dalam pelaksanaan proses penyidikan serta terwujudnya pelaksanaan penyidikan yang bersinergi dan profesional.

Namun demikian, fakta di lapangan menunjukkan bahwa keberadaan PPNS KI di lingkungan Kementerian Hukum dan HAM belum memberikan kontribusi yang siginifikan terhadap penegakan hukum kekayaan intelektual. Berdasarkan dataset putusan pidana kekayaan intelektual yang ada, penyidikan cenderung dilakukan oleh pihak kepolisian ketimbang PPNS, sebagaimana tersaji dalam Tabel 1 berikut:

Tabel 1.

Dataset Putusan Pidana Kekayaan Intelektual

\begin{tabular}{|c|c|c|c|c|c|}
\hline No. & Yurisdiksi & Nomor Putusan. & Pasal/UU/Pasal & KI & Penyidik \\
\hline 1 & $\begin{array}{l}\text { PN } \\
\text { Bukittinggi }\end{array}$ & $\begin{array}{l}\text { No. 74/ Pid.B } \\
\text { /2013/PN .Bt }\end{array}$ & $\begin{array}{l}\text { Pasal } 72 \text { ayat (2) UU No. } \\
19 \text { tahun } 2002 \text { tentang Hak } \\
\text { Cipta }\end{array}$ & Hak Cipta & $\begin{array}{l}\text { Ditreskrimsus Polda } \\
\text { Sumbar }\end{array}$ \\
\hline 2 & PN Kediri & $\begin{array}{l}\text { 180/Pid. } \\
\text { Sus/2013/PN. } \\
\text { Kdi. }\end{array}$ & $\begin{array}{l}\text { Pasal } 72 \text { Ayat (2) Undang- } \\
\text { Undang RI No. } 19 \text { Tahun } \\
2002 \text { tentang } \\
\text { Hak Cipta }\end{array}$ & Hak Cipta & Kepolisian \\
\hline 3 & PN Kediri & $\begin{array}{l}181 \text { / Pid.Sus / } \\
2013 \text { / PN. Kdi }\end{array}$ & $\begin{array}{l}\text { Pasal } 72 \text { Ayat (2) Undang- } \\
\text { Undang RI No. } 19 \text { Tahun } \\
2002 \text { tentang } \\
\text { Hak Cipta }\end{array}$ & Hak Cipta & Kepolisian \\
\hline 4 & $\begin{array}{l}\text { Mahkamah } \\
\text { Agung }\end{array}$ & $\begin{array}{l}\text { 1010 K/Pid. } \\
\text { Sus/2013 }\end{array}$ & $\begin{array}{l}\text { Pasal } 72 \text { ayat (3) 5Undag- } \\
\text { Undang Nomor : } 19 \text { Tahun } \\
2002 .\end{array}$ & Hak Cipta & Ditreskrim Polda Jatim \\
\hline 5 & $\begin{array}{l}\text { PN Jakarta } \\
\text { Pusat }\end{array}$ & $\begin{array}{l}\text { 2368/Pid.B/2007/ } \\
\text { PN .Jkt .Pst }\end{array}$ & $\begin{array}{l}\text { Pasal 90, Pasal } 91 \text { dan Pasal } \\
93 \text { Undang-Undang No.15 } \\
\text { Tahun } 2001 \text { tentang } \\
\text { Merek }\end{array}$ & Merek & $\begin{array}{l}\text { Polres Jakarta Pusat } \\
\text { Ket. Ahli: Ditjen KI. }\end{array}$ \\
\hline 6 & $\begin{array}{l}\text { PN Jakarta } \\
\text { Pusat }\end{array}$ & $\begin{array}{l}\text { No. } 1778 / \\
\text { Pid.B/2011/PN. } \\
\text { Jkt .Pst }\end{array}$ & $\begin{array}{l}\text { Pasal } 90 \text { Undang-Undang } \\
\text { RI No. } 15 \text { Tahun } 2001\end{array}$ & Merek & $\begin{array}{l}\text { Direktorat Reserse } \\
\text { Kriminal Khusus Polda } \\
\text { Metro Jaya } \\
\text { Ket. Ahli: Ditjen KI. }\end{array}$ \\
\hline 7 & $\begin{array}{l}\text { PN Jakarta } \\
\text { Pusat }\end{array}$ & $\begin{array}{l}\text { 1781/Pid. } \\
\text { Sus/2013/PN. Jkt } \\
\text {.Pst. }\end{array}$ & $\begin{array}{l}\text { Pasal } 94 \text { ayat (1) Undang- } \\
\text { Undang RI No.15 tahun } \\
2001 \text { tentang Merek }\end{array}$ & Merek & $\begin{array}{l}\text { Kepolisian Unit V } \\
\text { Subdit I Indag Dit. } \\
\text { Reskrimsus Polda } \\
\text { Metro Jaya. }\end{array}$ \\
\hline
\end{tabular}




\begin{tabular}{|c|c|c|c|c|c|}
\hline 8 & $\begin{array}{l}\text { PN Jakarta } \\
\text { Pusat }\end{array}$ & $\begin{array}{l}\text { 579/Pid.B/2013/ } \\
\text { PN J.Jkt. Pst. }\end{array}$ & $\begin{array}{l}\text { Pasal } 94 \text { jo } 91 \text { UU No. } 15 \\
\text { tahun } 2001\end{array}$ & Merek & $\begin{array}{l}\text { Kepolisian } \\
\text { Ketereangan Ahli dari } \\
\text { Ditjen KI }\end{array}$ \\
\hline 9 & $\begin{array}{l}\text { Pengadilan } \\
\text { Tinggi } \\
\text { Jakarta }\end{array}$ & $\begin{array}{l}\text { 72/Pid/2014/PT } \\
\text {.DKI }\end{array}$ & $\begin{array}{l}\text { pPasal } 94 \text { ayat (1) Undang- } \\
\text { undang Nomor } 15 \text { Tahun } \\
2001 \text { Tentang Merek, }\end{array}$ & Merek & $\begin{array}{l}\text { Sentra Pelayanan } \\
\text { Kepolisian Terpadu } \\
\text { Polda Metro Jaya } \\
\text { Ket. Ahli: Ditjen KI }\end{array}$ \\
\hline 10 & $\begin{array}{l}\text { PN } \\
\text { Surakarta }\end{array}$ & $\begin{array}{l}\text { 75/Pid.Sus/2015/ } \\
\text { PN Skt. }\end{array}$ & $\begin{array}{l}\text { Pasal } 91 \text { UU No. } 15 \text { tahun } \\
2001\end{array}$ & Merek & $\begin{array}{l}\text { Kepolisian } \\
\text { Ket. Ahli: Ditjen KI }\end{array}$ \\
\hline 11 & $\begin{array}{l}\text { PN } \\
\text { Surakarta }\end{array}$ & $\begin{array}{l}\text { 80/Pid.Sus/2015/ } \\
\text { PN Skt. }\end{array}$ & $\begin{array}{l}\text { Pasal } 94 \text { ayat (1) dan (2) } \\
\text { UU } 15 \text { Tahun } 2001\end{array}$ & Merek & $\begin{array}{l}\text { Kepolisian } \\
\text { Ket. Ahli: Ditjen KI }\end{array}$ \\
\hline 12 & $\begin{array}{l}\text { Mahkamah } \\
\text { Agung }\end{array}$ & $\begin{array}{l}332 \mathrm{~K} / \text { Pid. } \\
\text { Sus/2013 }\end{array}$ & $\begin{array}{l}\text { Pasal } 17 \text { ayat (1) UU } \\
\text { Nomor } 30 \text { Tahun } 2000 \\
\text { tentang Rahasia Dagang, }\end{array}$ & $\begin{array}{l}\text { Rahasia } \\
\text { Dagang }\end{array}$ & $\begin{array}{l}\text { - } \\
\text { Ket. Ahli: Putu } \\
\text { Dharmayasa, S.H. } \\
\text { Kasub Pelayanan } \\
\text { Hukum Umum Kanwil } \\
\text { Kementerian Hukum } \\
\text { dan Ham Propinsi } \\
\text { Sulawesi } \\
\text { Tengah }\end{array}$ \\
\hline
\end{tabular}

Sumber: Dataset Putusan Pidana Kekayaan Intelektual yang Diolah oleh Penulis, 2019.

\section{B. Metode Penelitian}

Kajian ini bersifat deskriptif dan eksplanatif yang akan menggambarkan efektivitas penegakan hukum oleh PPNS di bidang kekayaan intelektual, serta menjelaskan hal-hal yang memengaruhi efektivitas tersebut. Untuk dapat dikategorikan dalam kondisi efektif, kajian ini menetapkan beberapa parameter yang akan dijadikan ukuran, dengan pertama-tama berangkat dari normativitas tugas dan kewenangan yang diemban oleh PPNS. ${ }^{6}$ Berdasarkan pada norma-norma tersebut, kajian ini merumuskan ruang lingkup evaluasi efektivitas penegakan hukum di bidang kekayaan intelektual oleh PPNS sebagai berikut: (i) pelaksanaan penyidikan; (ii) pelaksanaan koordinasi dengan kepolisian; dan (iii) SDM PPNS yang berkualitas.
Berdasarkan ruang lingkup tersebut, penelitian ini lebih lanjut merumuskan objek/ parameter evaluasi ke dalam dua kategori, yakni: efektivitas penegakan hukum dari sisi internal dan eksternal. Dalam hal ini, efektivitas internal akan melibatkan dua parameter yang mencakup: pelaksanaan manajemen (termasuk kelembagaan) penyidikan dan karier PPNS. Sedangkan dari sisi eksternal, parameter evaluasi akan mencakup norma/regulasi tentang penegakan hukum KI oleh PPNS dan pola koordinasi yang dilakukan oleh PPNS. Penetapan terhadap empat parameter/objek evaluasi ini karena dianggap sebagai faktor yang memengaruhi praktik penegakan hukum.

Berdasarkan parameter dan indikator yang ada, kajian ini mengumpulkan data primer melalui 
wawancara dengan informan yang meliputi: pejabat PPNS di Direktorat Jenderal Kekayaan Intelektual, pejabat di lingkungan Direktorat Penyidikan dan Penyelesaian Sengketa dan di tingkat wilayah (secara purposif, kajian ini akan dilakukan di Kantor Wilayah Hukum dan HAM yang memiliki jumlah tenaga PPNS aktif paling banyak, yakni di Provinsi Bali dengan sembilan orang pejabat); serta informan lain terkait yang dianggap relevan, seperti pihak kepolisian. Data sekunder juga dikumpulkan melalui pengumpulan putusan-putusan pengadilan terkait tindak pidana kekayaan intelektual, data statistik Direktorat Jenderal Kekayaan Intelektual.

\section{Hasil Penelitian dan Pembahasan}

Sebagaisalahsatunegarayangmenandatangani persetujuan pembentukan organisasi perdagangan dunia (World Trade Organization/WTO) dan perjanjian mengenai aspek-aspek perdagangan yang terkait dengan Hak Kekayaan Intelektual (Agreement on Trade Related Aspects of Intellectual Property Rights/ TRIPs Agreement) sebagai salah satu lampirannya, Indonesia telah menerbitkan serta melakukan beberapa penyesuaian kerangka normatif perlindungan kekayaan intelektual.?

Dalam kerangka hukum, upaya perlindungan negara terhadap kekayaan intelektual tidak hanya berhenti pada tahapan pendaftaran yang bersifat administratif, namun juga wajib menyentuh pada level penegakan (enforcement) yang bersifat yuridis. Untuk itu, sebagai organ pemerintah yang menjadi penanggungjawab perlindungan kekayaan intelektual di Indonesia, Kementerian Hukum dan HAM diberikan mandat oleh undang-undang untuk tidak hanya melaksanakan layanan pendaftaran, tetapi juga mencakup kewenangan penegakan hukum dalam rupa kewenangan untuk melakukan penyidikan.

Namun demikian, upaya perlindungan kekayaan intelektual di Indonesia masih kerap menemui tantangan serta kendala, khususnya pada tingkat penegakan hukum. Berdasarkan temuan yang dirilis oleh Office of the United States Trade Representative, Indonesia masuk ke dalam priority watch list Pemerintahan Amerika Serikat sejak 2016 hingga 2017. ${ }^{8}$ Laporan-laporan tersebut dengan demikian mengindikasikan bahwa penegakan hukum kekayaan intelektual masih menemukan tantangan khususnya terhadap keberlakuan hukum pidana yang dapat memberikan efek jera di tengah masyarakat. ${ }^{9}$

\section{Mekanisme Penegakan Hukum Kekayaan Intelektual}

Kajian ini memfokuskan diri pada aspek penegakan hukum pidana kekayaan intelektual, namun juga diperlukan penggambaran terhadap mekanisme penegakan hukum bidang kekayaan intelektual secara umum. Hal ini akan berguna dalam rangka mendudukkan posisi penegakan hukum pidana sebagai salah satu mekanisme penegakan hukum kekayaan intelektual. Beranjak dari proposisi tersebut, eksistensi dan penerapan mekanisme lainnya di luar kerangka hukum pidana akan sangat memberikan pengaruh terhadap penilaian efektivitas penegakan hukum yang dilakukan oleh penyidik. Mengingat saluran (channel) yang dapat diakses oleh para pihak yang menduga terjadi pelanggaran hak kekayaan intelektual tidak tunggal. ${ }^{10}$

Berdasarkan kerangka normatif yang berlaku, termasuk dinamika perkembangan pembentukan dan penegakan hukum yang ada, terdapat setidaknya

\footnotetext{
Undang-Undang No. 7/1994 tentang Pengesahan Agreement Establishing The WorldTrade Organization (Persetujuan Pembentukan Organisasi Perdagangan Dunia)

Office of the United States Trade Representative, Special 301 Report, 2016 \& 2017.

Michael Blakeney, Guidebook on Enforcement of Intellectual Property Rights, Queen Mary Intellectual Property Research Institute, Queen Mary, University of London, n.d, hlm. 41.

10 Ari Wibowo, "Justifikasi Hukum Pidana terhadap Kebijakan Kriminalisasi Pelanggaran Hak Cipta, serta Perumusan Kualifikasi Yuridis dan Jenis Deliknya”, Jurnal Hukum Ius Quia Iustum, Vol. 22, No. 1, Januari 2015 (54-75), hlm. 72. Wibowo menyatakan bahwa, “... dalam praktiknya, apabila terjadi pelanggaran hak cipta, pihak yang hak ciptanya dilanggar lebih menginginkan adanya ganti rugi dari pihak yang melanggar hak cipta ketimbang pelanggar hak cipta tersebut dikenakan pidana penjara atau denda. Oleh karena itu, penyelesaiannya diupayakan secara damai di luar pengadilan.” hlm. 72.
} 
tiga bentuk mekanisme penegakan hukum yang diatur di dalam undang-undang di bidang kekayaan intelektual, yakni: penyelesaian sengketa, penetapan sementara pengadilan, dan penegakan hukum pidana kekayaan intelektual. ${ }^{11}$ Berdasarkan hal tersebut, dapat dipahami bahwa penegakan hukum pidana kekayaan intelektual mengacu pada KUHAP sebagai hukum formil. Adapun hukum materiilnya diatur secara khusus dalam undang-undang sektoral hukum kekayaan intelektual.

Secara umum, pidana kekayaan intelektual bersifat delik aduan (klacht), yakni pihak yang mengadukan haruslah pihak mengalami kerugian. ${ }^{12}$ Konstruksi delik aduan tersebut mempunyai implikasi berbeda dengan delik biasa, dimana pengaduan adalah syarat untuk penuntut umum melakukan penuntutan. ${ }^{13}$ Jika aduan dicabut, maka proses penegakan hukum akan dihentikan. Berbeda dengan delik biasa (bersifat laporan), siapapun dapat melaporkan adanya kejadian pidana dan proses penegakan hukum tidak dapat dihentikan meskipun telah terjadi perdamaian antara pihak yang bersengketa. Ketentuan tersebut sudah barang tentu memberi konsekuensi hukum formil yang berbeda dalam kerangka penegakan hukum kekayaan intelektual.

Dinamika penegakan hukum pidana kekayaan intelektual turut berkembang seiring adanya uji materi terhadap beberapa pasal KUHAP yang dikabulkan Mahkamah Konstitusi, antara lain: 65/ PUU-VIII/2010 mengenai definisi saksi dalam KUHAP; 21/PUU-XII/2014 tentang perluasan objek Praperadilan; dan 130/PUU-XIII/2015 tentang jangka waktu penerbitan dan pemberitahuan
SPDP kepada penuntut umum, pelapor/korban, dan terlapor. Setiap putusan MK tersebut berimplikasi pada proses penegakan hukum, termasuk penegakan hukum oleh PPNS KI (KI). Implikasi yang paling signifikan mempengaruhi kinerja PPNS KI adalah Putusan MK Nomor 130/PUU-XIII/2015, yang secara langsung menuntut PPNS KI untuk melengkapi administrasi penyidikan secara lebih cepat demi kelancaran proses penegakan hukum.

Putusan Mahkamah Konstitusi Nomor 130/ PUU-XIII/2015 tersebut pada intinya menyatakan bahwa Pasal 109 ayat (1) KUHAP tidak mempunyai kekuatan hukum mengikat sepanjang tidak dimaknai penyidik wajib memberitahukan dan menyerahkan surat perintah dimulainya penyidikan (SPDP-pen) kepada penuntut umum, terlapor, dan korban/ pelapor dalam waktu paling lambat 7 (tujuh) hari setelah dikeluarkannya surat perintah penyidikan. Implikasi putusan tersebut terhadap penegakan hukum kekayaan intelektual adalah di dalam proses penyelidikan dan penyidikan, PPNS KI harus lebih cepat dalam memastikan ada atau tidaknya tindak pidana, serta dalam mengumpulkan barang bukti dan alat bukti yang berhubungan dengan tindak pidana. Jika jangka waktu 7 (tujuh) hari tersebut tidak dapat dipenuhi penyidik, maka penyidikan dinyatakan batal demi hukum dan kejaksaan dapat menolak pelimpahan berkas penyidikan.

Kendala yang muncul kemudian adalah ketika SPDP harus diberikan kepada penuntut umum selambat-lambatnya 7 (tujuh) hari setelah terbitnya surat perintah penyidikan, PPNS KI mengalami kesulitan dalam menentukan nama tersangka dalam di SPDP tersebut. ${ }^{14}$ Dalam hal ini,

11 Dalam studi yang lain, yang pada derajat tertentu memiliki relevansi dengan penegakan hukum kekayaan intelektual, Raharjo membagi kategori penegakan hukum perkara pidana ke dalam dua model umum, yakni: model litigasi dan non-litigasi. Untuk yang terakhir, Raharjo mengajukan model plea bargaining sebagai bentuk model non-litigasi dalam penegakan hukum pidana. Lihat, Agus Raharjo, "Mediasi sebagai Basis dalam Penyelesaian Perkara Pidana, Mimbar Hukum, Vol. 20, No. 1, Februari 2008, hlm.91-109. Secara lebih spesifik terkait model non-litigasi, Mulyadi menyebutkan pula adanya frasa mediasi penal dalam sistem peradilan pidana di Indonesia. Lihat Lilik Mulyadi, "Mediasi Penal dalam Sistem Peradilan Pidana Indonesia: Pengkajian Asas, Norma, Teori dan Praktik", Yustisia, Vol.2, No.1 Januari - April 2013, hlm 1-14.

12 Kecuali tindak pidana yang diatur dalam Pasal 163 UU No. 13 Tahun 2016 tentang Paten. Lihat R. Tresna, Azas-azas Hukum Pidana Disertai Pembahasan Beberapa Perbuatan Pidana yang Penting, Tiara, Jakarta.

13 Berdasarkan Pasal 1 angka (25) KUHAP, "Pengaduan" adalah pemberitahuan dan permintaan oleh yang berkepentingan kepada pejabat yang berwenang untuk menindak menurut hukum seseorang yang telah melakukan tindak pidana aduan yang merugikannya.

14 Keterangan Ahli Dr. Chairul Huda, S.H., M.H. dalam Putusan Mahkamah Konsitusi Nomor 130/PUU/XIII/2015, hlm. 126. Keterangan ini juga diperkuat oleh hasil wawancara dengan Ignatius MT Silalahi, Kepala Subdirektorat Penindakan dan Pemantauan Direktorat Penyidikan dan Penyelesaian Sengketa Ditjen KI, pada 07 September 2017. 
perlu dipahami bahwa penyidikan kasus pidana kekayaan intelektual memerlukan koordinasi dan keahlian tertentu yang seringkali sulit untuk dilalui dalam waktu singkat. Padahal di sisi lain, ketentuan ini menuntut PPNS KI untuk lebih memantapkan proses penyelidikan; selain harus bisa menentukan suatu kejadian sebagai tindak pidana atau bukan, juga sudah harus mempersiapkan barang bukti dan tersangka. Menimbang kondisi riil PPNS KI yang ada saat ini, putusan tersebut semakin mempersulit proses penegakan hukum kekayaan intelektual oleh PPNS KI. ${ }^{15}$

\section{Posisi PPNS dalam Penegakan Hukum Kekayaan Intelektual}

Secara umum, legitimasi Penyidik Pegawai Negeri Sipil (PPNS) ada dalam Pasal 6 ayat (1) huruf b Undang-Undang Nomor 8 Tahun 1981 tentang Kitab Undang-Undang Hukum Acara Pidana (KUHAP). ${ }^{16}$ Berdasarkan aturan tersebut, PPNS merupakan penyidik yang diberi kewenangan khusus berdasarkan undang-undang sektoral (vide Pasal 7 ayat (2) KUHAP), misalnya, di sektor tindak pidana kehutanan kehutanan ada Polisi Khusus Kehutanan yang diatur dalam UU Kehutanan, PPNS di sektor perhubungan dalam UU Lalu Lintas dan Jalan Raya, dan lain sebagainya. Patut dipahamiPerlu diketahui bahwa ketika melaksanakan tugas penyidikan, PPNS juga melaksanakan fungsi penyelidikan, dimana kedua fungsi tersebut tidak berdiri sendirisendiri, melainkan sebuah kesatuan. ${ }^{17}$

Beberapa dasar hukum mengenai PPNS selanjutnya diatur dalam Peraturan Kepala Kepolisian Negara Republik Indonesia Nomor 6 Tahun 2010 tentang Manajemen Penyidikan oleh
Penyidik Pegawai Negeri Sipil. Aturan tersebut mengatur pola koordinasi teknis antara PPNS dan Penyidik Polri serta pengawasan tugas dan fungsi penyidikan PPNS oleh Penyidik Polri. ${ }^{18}$ Selain itu, dasar hukum PPNS terdapat dalam Peraturan Pemerintah Republik Indonesia Nomor 43 Tahun 2012 tentang Tata Cara Pelaksanaan Koordinasi, Pengawasan, dan Pembinaan Teknis Terhadap Kepolisian Khusus, Penyidik Pegawai Negeri Sipil, dan Bentuk-bentuk Pengamanan Swakarsa. ${ }^{19}$

Secara khusus dalam tindak pidana kekayaan intelektual, pembantu fungsi kepolisian adalah PPNS KI. Dasar hukum penyidikan oleh PPNS KI diatur dalam setiap peraturan perundang-undangan sektoral KI. Berangkat dari narasi tersebut, fungsi kepolisian dalam tindak pidana kekayaan intelektual berada dalam domain kewenangan PPNS KI, sedangkan fungsi pengawasan dan koordinasi dalam konteks penyidikan tetap diemban Penyidik Polri, melalui Korwas PPNS. Penyidik Polri juga bertugas memberikan bimbingan teknis kepada PPNS terkait pelaksaan fungsi kepolisian. Dalam praktiknya, jika aduan tindak pidana KI dialamatkan ke kepolisian, maka penyelidikan dan penyidikan dilakukan oleh kepolisian dengan melibatkan PPNS KI dalam memberikan keterangan ahli. ${ }^{20}$. Sebaliknya, jika aduan tindak pidana KI dialamatkan pada Ditjen KI, maka PPNS KI melakukan penyelidikan dan penyidikan dengan berkoordinasi dengan Kepolisian dalam kerangka administrasi dan etika penyelidikan dan penyidikan. ${ }^{21}$

Secara lebih teknis, Kementerian Hukum dan HAM telah menerbitkan Keputusan Menteri No. M.HH-01.H1.07.02 Tahun 2015 tentang Petunjuk Pelaksanaan Manajemen Penydikan Tindak Pidana

15 Wawancara dengan Ignatius MT Silalahi, Kepala Subdirektorat Penindakan dan Pemantauan Direktorat Penyidikan dan Penyelesaian Sengketa Ditjen KI, pada 07 September 2017.

6 Pasal 6 ayat (1) huruf b KUHAP

17 M. Yahya Harahap, 2006, Pembahasan Permasalahan dan Penerapan KUHAP: Penyidikan dan Penuntutan, Sinar Grafika, hlm. 101.

18 Peraturan Kepala Kepolisian Negara Republik Indonesia tentang Manajemen Penyidikan oleh Penyidik Pegawai Negeri Sipil, Perkapolri No. 6/ 2010, bagian Menimbang, huruf a dan b.

19 Pasal 3 Peraturan Pemerintah Nomor 43 Tahun 2012 tentang Tata Cara Pelaksanaan Koordinasi, Pengawasan, dan Pembinaan Teknis terhadap Kepolisian Khusus, Penyidik Pegawai Negeri Sipil, dan Bentuk-bentuk Pengamanan Swakarsa (Lembaran Negara Republik Indonesia Tahun 2012 Nomor 74, Tambahan Lembaran Negara Republik Indonesia Nomor 5298).

20 Wawancara dengan Ignatius MT Silalahi, Kepala Sub Direktorat Penindakan dan Pemantauan Direktorat Penyidikan dan Penyelesaian Sengketa Ditjen KI, pada 07 September 2017. Padahal, secara normatif keterangan ahli diperoleh dari seseorang yang memiliki keahlian khusus; dalam hal ini seharusnya dari seseorang dalam kapasitasnya sebagai pejabat terkait kekayaan intelektual, bukan sebagai PPNS (Lihat Pasal 1 angka 28 UU No. 8 Tahun 1981 tentang Kitab Undang-Undang Hukum Acara Pidana)

$21 \quad$ Ibid. 
di Bidang Kekayaan Intelektual. Keputusan ini diterbitkan dengan dasar pertimbangan bahwa, "proses penanganan tindak pidana di bidang kekayaan intelektual apabila dilaksanakan secara efektif dan efisien dapat memberikan manfaat yang besar dan optimal dalam upaya peningkatan perlindungan terhadap kekayaan intelektual." Dengan begitu, dapat dipahami bahwa kebijakan teknis internal tersebut diarahkan pada bagaimana mekanisme penyidikan, yang berada di bawah kendali dan kewenangan Kementerian Hukum dan HAM, dapat secara efektif dan efisien mendukung perlindungan kekayaan intelektual. Secara substansial, Petunjuk Pelaksanaan (Juklak) ini mengatur empat aspek utama dalam manajemen penyidikan, yakni: penerimaan dan pencatatan laporan, alat bukti dalam tindak pidana kekayaan intelektual; tata cara penyidikan; dan mediasi. ${ }^{22}$

\section{Efektivitas Penegakan Hukum Kekayaan Intelektual oleh PPNS}

Berdasarkan tinjauan terhadap beberapa putusan pengadilan atas tindak pidana pelanggaran kekayaan intelektual, posisi Direktorat Jenderal Kekayaan Intelektual mayoritas berada dalam porsi memberikan keterangan ahli. ${ }^{23}$ Umumnya, aduan tindak pidana kekayaan intelektual dialamatkan ke kepolisian untuk kemudian dilakukan penyidikan dan melibatkan PPNS KI untuk memberikan keterangan ahli. Fenomena seperti ini ditemukan dalam beberapa putusan pengadilan kasus tindak pidana kekayaan intelektual. ${ }^{24} \mathrm{Jika}$ dicermati, pola yang disebutkan di atas terjadi di wilayah hukum pengadilan yang ada di Jakarta. Tentu pola tersebut tidak serta merta menggambarkan pola penegakan hukum kekayaan intelektual di luar wilayah Jakarta. Beberapa putusan pengadilan tentang tindak pidana kekayaan intelektual di luar wilayah Jakarta justru menunjukkan hal sebaliknya, yakni proses penegakan hukum kekayaan intelektual secara tersendiri dilakukan oleh kepolisian. ${ }^{25}$

Dari 5 (lima) kasus tindak pidana kekayaan intelektual yang diadili di luar wilayah Jakarta, terdapat 3 (tiga) perkara yang tidak melibatkan Ditjen KI, sementara 2 (dua) perkara lainnya melibatkan Ditjen KI sebagai ahli. Hal ini menunjukkan bahwa Kanwil Hukum dan HAM selaku perpanjangan tangan Kementerian Hukum dan HAM absen dalam proses penegakan hukum KI. Data tersebut juga menunjukkan belum maksimalnya fungsi perpanjangan tangan Ditjen KI di daerah. Meskipun perlu dicermati lebih lanjut faktor-faktor penyebab minimnya fungsi perpanjangan tangan Ditjen KI di daerah.

Salah satu entry point dalam melihat faktor penyebab minimnya fungsi perpanjangan tangan Ditjen KI di daerah adalah dengan melihat data laporan kejadian dugaan tindak pidana kekayaan intelektual kepada Ditjen KI. ${ }^{26}$ Berdasarkan data tersebut, beberapa kasus dengan TKP di yurisdiksi Kanwil Hukum dan HAM tetap melibatkan Ditjen KI dalam proses penyidikan. Selain itu, peneliti menemukan fakta bahwa ada kasus-kasus pidana kekayaan intelektual yang tidak melalui birokrasi Kanwil. Walaupun tidak diwajibkan secara normatif, namun hal ini mengindikasikan ketidakefektifan proses penyidikan yang ada di wilayah. Salah satu informan menyatakan hal tersebut:

"Kasus-kasus kekayaan intelektual dengan TKP di Provinsi Bali kebanyakan ditangani oleh Ditjen KI. Saya secara pribadi pernah

22 Lampiran Keputusan Menteri Hukum dan HAM No. M.HH-01.H1.07.02 Tahun 2015 tentang Petunjuk Pelaksanaan Manajemen Penydikan Tindak Pidana di Bidang Kekayaan Intelektual.

23 Putusan pengadilan yang dimaksud adalah Putusan Tingkat Pertama dan Putusan Kasasi yang diperoleh dari situs https://putusan. mahkamahagung.go.id/pengadilan/mahkamah-agung/direktori/pidana-khusus/kejahatan-merek yang secara acak memuat putusan tindak pidana kekayaan intelektual dari seluruh Pengadilan Negeri di Indonesia.

24 Seperti Putusan Nomor: 2368/Pid.B/2007/PN.JKT.PST, 1778/Pid.B/2011/PN.JKT.PST, 579/Pid.B/2013/ PN.JKT.PST, 1430/Pid.B/2013/ PN.JKT.UT/2013, 1243/Pid.Sus/2013/PN.JKT.BAR.

25 Lih. PN Bukittinggi No. 74/Pid.B/2013/PN.BT; PN Kediri No. 180/Pid.Sus/2013/PN.KDI; PN Kediri No. 181/Pid.Sus/2013/PN.KDI; PN Surakarta No. 80/Pid.Sus/2-05/PN.SKT; PN Surakarta No. 75/Pid.Sus/2015/PN.SKT.

26 Data administrasi penyidikan diperoleh dari Direktorat Penyidikan dan Penyelesaian Sengketa Direktorat Jenderal Kekayaan Intelektual Kementerian Hukum dan HAM RI Tahun 2015-2017. 
menangani kasus kekayaan intelektual tanpa sepengetahuan Kanwil Bali, beberapa contoh kasus yang pernah ditangani seperi kasus hak cipta dan kasus desain industri." ${ }^{27}$

Informan melanjutkan bahwa situasi tersebut dipengaruhi oleh faktor internal PPNS itu sendiri:

"Kebanyakan kasus kekayaan intelektual yang ditangani selesai secara mediasi; kebanyakan PPNS yang ada di Kanwil Bali terkesan kurang percaya diri, sehingga jika ada aduan masuk tidak langsung ditangani sendiri, melainkan menanyakan lebih dulu ke pusat." ${ }^{28}$

Pengalaman yang relatif serupa disampaikan oleh seorang informan PPNS lain, dengan menyatakan bahwa:

"Aduan masyarakat yang masuk ke Kanwil Bali relatif sedikit. Di tahun 2017 ada 1 (satu) aduan tentang perkara merek. Kasus tersebut diadukan ke Polsek Gianyar yang bersamasama PPNS KI di Kanwil Bali melakukan penyidikan. PPNS KI juga pernah terlibat dalam kasus merek karung beras. Pada kasus ini PPNS KI terlibat dalam kapasitas memberikan keterangan ahli. Sebelum terbit UU No 20 Tahun 2016 tentang Merek dan Indikasi Geografis PPNS KI banyak dilibatkan untuk memberi keterangan ahli terkait kasus merek". ${ }^{29}$

Kendala yang dihadapi oleh PPNS di tingkat wilayah, sebagaimana disampaikan oleh informan, meliputi:

"Situasi PPNS KI di daerah terkendala dengan adanya tumpang tindih tugas dan fungsi dan juga jabatan. Tenaga PPNS KI di Kanwil Bali banyak merangkap jabatan lain sehingga mempunyai wilayah kerja yang lain dan tidak bisa fokus melaksanakan tugas dan fungsi PPNS ... Permasalahan PPNS KI di Kanwil Bali dapat disimpulkan sebagai berikut: kekurangan SDM PPNS KI, ketidaktahuan masyarakat akan eksistensi PPNS KI di Kanwil Bali, tugas pegawai di Kanwil Bali yang bermacam-macam selain sebagai PPNS mengakibatkan pelaksanaan tugas PPNS kurang fokus. Selain itu minimnya sosialisasi hukum kekayaan intelektual kepada masyarakat juga mempengaruhi efektivitas kerja PPNS KI di Kanwil. Postur anggaran dalam DIPA dan struktur organisasi di bawah Divisi Pelayanan Hukum perlu dikaji untuk efektivitas tugas dan fungsi PPNS KI di Kanwil. Postur anggaran yang ada sekarang tidak dapat mengakomodir pelaksanaan tugas dan fungsi PPNS KI dengan baik." 30

Dengan begitu, lebih lanjut menurut informan, fungsi PPNS KI di Kanwil Bali hanya sebagai tugas tambahan, padahal secara normatif, PPNS mempunyai tugas yang fundamental dalam penegakan hukum. PPNS berwenang melakukan olah TKP sebagaimana diatur Pasal 20 ayat (1) Peraturan Kepala Kepolisian Negara Republik Indonesia Nomor 6 Tahun 2010 tentang Manajemen Penyidikan oleh Penyidik Pegawai Negeri Sipil, yaitu untuk melakukan tindakan (a) mencari keterangan, petunjuk, barang bukti serta identitas tersangka dan korban maupun saksi untuk kepentingan penyelidikan selanjutnya, dan (b) pencarian, pengambilan, pengumpulan, dan pengamanan barang bukti, yang dilakukan dengan metode tertentu atau bantuan teknis penyidikan seperti laboratorium forensik, identifikasi, kedokteran forensik, dan bidang ahli lainnya.

Pada sisi pelaksanaan koordinasi dengan pihak kepolisian, informan dari Kepolisian Daerah Bali menyatakan bahwa koordinasi dalam penyidikan kasus-kasus pidana kekayaan intelektual relatif minim. ${ }^{31}$ Sejauh ini, menurut informan baru satu kasus yang dikoordinasikan oleh PPNS KI di Kantor Wilayah, yang terjadi di 2015. Menurut informan:

"Bentuk koordinasi antara Kanwil Bali dan Polda Bali adalah dalam hal meminta pihak polda untuk menjadi narasumber dalam 
forum rapat koordinasi teknis. Selain itu pihak kanwil juga berkoordinasi dalam hubungannya dengan kartu PPNS. Jika kartu PPNS tersebut sudah habis masa berlakunya, PPNS di tempat lain berkoordinasi dengan korwas polda bali untuk perpanjangan masa berlaku kartu PPNS. Dibandingkan dengan PPNS di Kementerian lain, koordinasi dengan PPNS KI relatif minim, karena aduan kepada PPNS KI pun minim.”

Pernyataan tersebut diperkuat dengan keterangan informan dari Subdit Perdagangan dan Perindustrian, Ditreskrimsus Polda Bali, yang memang secara substansial menangani kasus-kasus pelanggaran kekayaan intelektual. Selama ini, menurut informan:

"Koordinasi yang dilakukan Polda Bali dengan Kemenkumham terkait kasus kekayaan intelektual dalam bentuk meminta keterangan ahli dari Ditjen KI (pusat), dan tidak melakukan koordinasi dengan Kanwil Hukum dan HAM Provinsi Bali. Pihak Polda Bali meminta untuk menghadirkan ahli dari Ditjen KI. Kapasitas ahli dalam hal ini adalah memberikan keterangan mengenai pendaftaran merek, misalnya, apakah benar merek yang disengketakan ini sudah terdaftar sebelumnya, dan seterusnya. Sementara untuk substansi keaslian suatu barang diperiksa oleh Laboratorium Forensik di Polda Bali."

Berdasarkan keterangan tersebut, dapat diasumsikan bahwa secara praktis PPNS di Kantor Wilayah tidak memiliki peran dalam tahapan penyidikan. Kondisi tersebut secara langsung mendudukkan PPNS di Kantor Wilayah dalam posisi pasif, dalam konteks menunggu pelibatan dari Direktorat Jenderal KI atau dari kepolisian setempat untuk turut serta dalam penyidikan.

a. Efektivitas Internal

Berdasarkan data yang ada, kajian ini mencoba untuk mengaplikasikan parameter efektivitas sebagaimana tertera pada subbab metode kajian sebelumnya. Aspek efektivitas internal pertama-tama akan dilakukan analisis terhadap pelaksanaan manajemen penyidikan dan karier PPNS. Pada prinsipnya, manajemen penyidikan pelanggaran kekayaan intelektual sudah didukung oleh norma dan kelembagaan yang kuat. Sisi norma, Keputusan Menteri tentang Petunjuk Manajemen Penyidikan telah mengatur secara jelas aspek teknis substansial pelaksanaan, sehingga secara normatif dapat mendukung upaya penegakan hukum kekayaan intelektual. Sisi kelembagaan, pembentukan Direktorat Penyidikan dan Penyelesaian Sengketa merupakan dukungan kelembagaan terhadap pelaksanaan wewenang penyidikan berdasarkan undang-undang bidang kekayaan intelektual. ${ }^{32}$ Berdasarkan kedua sisi tersebut, kelembagaan pada tingkat pusat sesungguhnya telah dibentuk dalam rangka mendukung pelaksanaan kewenangan penyidikan. Namun, pada tingkat wilayah, patut diperhatikan bahwa meskipun tidak secara eksplisit tertera tentang kewenangan Kantor Wilayah untuk melakukan penyidikan, sedangkan upaya pengangkatan PPNS KI di hampir seluruh Kantor Wilayah diharapkan pelaksanaan penyidikan di tingkat wilayah dapat secara efektif berjalan.

Berdasarkan analisis sebelumnya, tampak bahwa efektivitas dari sisi internal PPNS KI dalam kerangka kerja penegakan hukum sudah berjalan dengan baik. Namun demikian, beberapa catatan perlu diperhatikan, yakni: pertama, data pada lokus penelitian menujukkan bahwa dalam melaksanakan fungsi penyidikan, prosesnya kerap tidak melalui jalur atau mekanisme birokrasi di Kanwil Hukum dan HAM, khususnya di Provinsi Bali; kedua, sumber daya PPNS KI baik di Direktorat Jenderal dan Kanwil Hukum dan HAM belum diposisikan dalam struktur yang mapan. 32 Peraturan Menteri Hukum dan Hak Asasi ManusiaAM Nomor 29 Tahun 2015 tentang Organisasi dan Tata Kerja Kementerian Hukum dan
HAM. 
Data menunjukkan bahwa kebanyakan PPNS KI mengemban jabatan-jabatan lain di lingkungan Kementerian Hukum dan HAM; bahkan beberapa ditempatkan di unit-unit yang tidak bersinggungan langsung dengan tugas sebagai PPNS, sehingga praktis tidak dapat menjalankan fungsi PPNS KI. Selain daripada itu, mutasi dan promosi pegawai yang dapat terjadi sewaktu-waktu menyebabkan jabatan penyidik tersebut ditinggalkan secara de facto. Hal ini mengakibatkan, efektivitas PPNS KI secara langsung terdampak dengan adanya fenomena tersebut, yakni dalam konteks berkurangnya jumlah personel PPNS KI yang menempati unit-unit teknis penegakan hukum KI, baik di Direktorat Jenderal Kekayaan Intelektual, maupun di Kanwil Hukum dan HAM. Khusus pada tingkat wilayah, fenomena ini menunjukkan indikasi belum adanya struktur jabatan PPNS KI yang mapan dan cenderung memunculkan penurunan motivasi bagi para PPNS untuk menjalankan fungsinya. Terlebih lagi, nomenklatur jabatan yang ada di Kanwil dianggap tidak dapat mengakomodasi kejelasan tugas dan fungsi PPNS KI pada tingkat wilayah. ${ }^{33}$

Meminjam teori Carl Jung, mengenai psychological type the cognitive function, secara psikologis bentuk efektivitas ogranisasi dapat dipetakan dalam model efisiensi dan efektivitas baik dari sisi internal maupun external. $^{34}$ Berdasarkan model tersebut, tinjauan terhadap efektivitas organisasi dapat dilihat secara psikologis, dalam pengertian bahwa konsep evaluasi permasalahan organisasi dan elemen-elemen yang mendukung efektivitas organisasi dianggap dipengaruhi faktor-faktor psikologis. ${ }^{35}$ Lebih lanjut dijelaskan Jung bahwa keempat elemen tersebut bersifat saling memengaruhi satu dengan yang lain, dan diperlukan suatu intervensi yang lebih pada salah satu unsur guna mengoptimalkan efektivitas organisasi secara keseluruhan.

Pada konteks PPNS KI, secara internal dapat didudukkan sebagai berikut: (1) dari aspek efisiensi, fungsi PPNS KI baik di tingkat pusat dan wilayah terkesan di-'nomorduakan'. Selain indikasi penurunan motivasi personel, belum jelasnya pola karier serta penganggaran yang optimal untuk penegakan hukum KI khususnya di tingkat wilayah, ${ }^{36}$ mengindikasikan belum optimalnya efektivitas fungsi PPNS. Sementara itu, pada beberapa kasus yang terjadi di wilayah Bali, proses penyidikan justru dilakukan oleh PPNS Ditjen KI dan bukan oleh PPNS di wilayah. Kondisi tersebut menyebabkan pembengkakan biaya penanganan perkara, yang seyogyanya dapat ditekan dengan melibatkan secara penuh PPNS KI di Kanwil Hukum dan HAM.

Efektivitas dan efisiensi tugas dan fungsi PPNS KI pun belum berada pada level ideal. Hal ini terbukti dari adanya PPNS KI yang menjabat jabatan tertentu di Kanwil, seperti jabatan struktural Eselon IV, Eselon III, dan staf di bagian kesekretariatan, yang memengaruhi fokus melaksanakan teknis PPNS KI. Selain itu, adanya mutasi/promosi pegawai di level daerah yang berada di luar kendali Ditjen KI, menyebabkan terdapat beberapa PPNS KI yang berkantor di Unit Pelaksana Teknis. ${ }^{37}$ Fenomena tersebut menyebabkan berkurangnya tenaga PPNS

Hasil wawancara dengan Informan \#2, PPNS di Kantor Wilayah Bali ,pada 13 September 2017.

Ralph H Kilmann, et.al., dan Richard P. Herden, (1976) Towards a Systemic Methodology for Evaluating the Impact of Inteventions on Organizational Effectiveness, Academy of Management Review, hlm. 92.

35 Ibid.

36 Wawancara dengan PPNS KI di Kanwil Hukum dan HAM Provinsi Bali pada 13 September 2017. (adanya revisi anggaran penegakan hukum KI di tahun berjalan. berbeda dengan PPNS KI di Ditjen KI yang memiliki anggaran memadai untuk penegakan hukum, Wawancara dengan Kepala Sub Direktorat Penindakan dan Pemantauan Direktorat Penyidikan dan Penyelesaian Sengketa Ditjen KI, pada 07 September 2017

37 Ibid. 
KI utamanya yang berada di daerah. Jadi, secara internal, kondisi PPNS KI di Kanwil Bali belum secara efektif dan efisien melaksanakan fungsi PPNS KI, baik dari segi manajemen penyidikan dan karir. Sedangkan pada tingkat pusat, perhatian utamanya pada kuadran efektivitas internal.

\section{b. Efektivitas Eksternal}

Dari sisi eksternal, efektivitas pelaksanaan penegakan hukum oleh PPNS dapat dilihat dari sisi regulasi dan bentuk pelaksanaan koordinasi dengan Kepolisian. Berdasarkan tinjauan regulasi yang ada, dapat dipahami bahwa mekanisme penegakan hukum kekayaan intelektual dapat dijalankan dengan beberapa jalur. Dengan demikian, kuantitas tindak pidana yang disidik oleh PPNS KI tidak dapat secara serta merta dianggap sebagai parameter efektivitas dari sisi regulasi. Perubahan norma yang dilakukan terhadap beberapa undangundang sektoral, seperti merek dan indikasi geografis, paten, dan hak cipta menunjukkan komitmen Indonesia terhadap penegakan hukum kekayaan intelektual. Khususnya terhadap pengaturan tindak pidana hak cipta sebagai delik aduan, dari sebelumnya berupa delik biasa yang dianggap "justru menimbulkan ketidaktenangan dan keresahan bagi para pengusaha dan pedagang karena kesempatan ini dimanfaatkan oleh oknum-oknum penegak hukum untuk mengintimidasi dan "mengintip-intip" serta mengintrogasi pedagang mengenai adanya dugaan pelanggaran hak cipta atas barang dagangannya." ${ }^{38}$

Adanya pengaturan tentang delik aduan tersebut, undang-undang yang mengatur tentang kekayaan intelektual pada prinsipnya mengadopsi mekanisme kuasi pidanaperdata. Hal ini mengingat terdapat unsur perdata dalam penyelesaian pidana kekayaan intelektual, yakni: adanya kesepakatan antar para pihak untuk menyelesaikan perkara pidana, baik melalui peradilan maupun tidak; adanya kesepakatan untuk menggunakan atau tidak menggunakan jasa seorang atau beberapa mediator; dan terjadi negosiasi atau tawar menawar mengenai jumlah ganti rugi atau tindakan lain yang harus diberikan atau dilakukan oleh pelaku kejahatan kepada pihak korban. ${ }^{39}$. Kondisi ketidakmutlakan penyelesaian perkara pidana kekayaan intelektual melalui jalur litigasi ini dianggap akan mendukung fungsi hukum pidana sebagai ultimum remidium. Melihat sisi lain, meskipun masih belum banyak digali dari sisi bukti empiris, keinginan untuk masuk ke dalam proses litigasi kekayaan intelektual dipengaruhi oleh biaya litigasi. ${ }^{40}$ Untuk itu, dari sisi efektivitas norma/ regulasi pada prinsipnya kerangka hukum di Indonesia sudah secara efektif memberikan perlindungan dan menyediakan mekanisme penegakan hukum, tidak hanya melalui litigasi, apabila terjadi pelanggaran kekayaan intelektual.

Selanjutnya pada sisi penyidikan oleh PPNS, ketentuan yang berlaku praktis tidak mengakomodasi kewenangan PPNS untuk terlibat di dalam mekanisme kuasi pidanaperdata tersebut. Regulasi yang ada cenderung untuk memosisikan PPNS dalam kerangka sistem penegakan hukum pidana semata, tanpa membuka ruang gerak pada ranah mediasi penal. Sedangkan dalam praktiknya, pihak Kepolisian sudah menerbitkan yang menjelaskan langkah-langkah penanganan

Ari Wibowo, Op.cit., hlm. 71.

Agus Raharjo, Op.cit., hlm. 103.

${ }^{40}$ Lih. Jean O. Lanjouw \& Josh Lerner, The Enforcement of Intellectual Property Rights: A Survey of the Empirical Literature, Working Paper 6296 National Bureau of Economic Researchm December 1997. 
kasus melalui ADR. ${ }^{41}$

Selain itu, pengaturan tentang penyelesaian sengketa alternatif kekayaan intelektual cukup beragam antar satu undangundang dengan yang lain. Dari seluruh undang-undang tentang kekayaan intelektual, hanya UU Paten yang menggariskan pengaturan bahwa "dalam hal terjadi tuntutan pidana terhadap pelanggaran Paten atau Paten sederhana para pihak harus terlebih dahulu menyelesaikan melalui jalur mediasi"; sedangkan undang-undang lainnya tidak mengatur tentang tata cara tersebut. Dengan demikian, sesungguhnya mediasi penal dapat dan perlu menjadi bagian dari tugas PPNS sebagai salah satu pemegang mandat penegakan hukum kekayaan intelektual. Hal ini tentu didukung fakta tingkat pemidanaan dan penghentian penyidikan yang menunjukkan bahwa penegakan hukum pidana kekayaan intelektual melalui jalur litigasi merupakan pilihan terakhir dari para pihak yang bersengketa.

Lebih jauh, ditinjau dari segi regulasi penyidikan, selain dasar hukum PPNS dan aturan teknis PPNS KI dalamPermenkumham, beberapa putusan MK terkait hukum acara pidana turut menciptakan ketimpangan proporsi antara tuntutan kinerja dengan kondisi SDM PPNS KI di pusat maupun daerah, yaitu beban kerja yang semakin berat tidak diimbangi dengan kuantitas sumber daya manusia PPNS KI baik di pusat maupun daerah. Terlebih lagi, kondisi PPNS KI di Kanwil Hukum dan HAM Provinsi Bali dapat dikatakan kurang memadai dari segi kuantitas yakni terdapat 5 (lima) orang PPNS yang juga menjabat jabatan struktural di
Kanwil Hukum dan HAM Bali.

Selanjutnya dari sisi koordinasi dengan Kepolisian, informasi dari Korwas PPNS Polda Bali mengindikasikan bahwa jumlah aduan kasus kekayaan intelektual kepada PPNS KI sepanjang 3 (tiga) tahun terakhir terbilang minim. Hal ini menyebabkan minimnya koordinasi teknis penyidikan dengan Polda Bali. Sedangkan kasus pidana KI yang diadukan ke Polda Bali, cenderung melibatkan Ditjen KI untuk memberikan keterangan ahli di proses penyidikan, dengan alasan legalitas hak kekayaan intelektual diterbitkan oleh Ditjen KI. ${ }^{42}$ Praktis, PPNS di Kanwil Hukum dan HAM Bali tidak mempunyai "panggung" manakala perkara diadukan ke kepolisian.

Dari sisi makro, patut dipahami pula bahwa hukum kekayaan intelektual relatif muda jika dibandingkan dengan ranah hukum lain yang ada di Indonesia memiliki pengaruh terhadap efektivitas penegakan hukum dari sisi eksternal. Untuk itu, menjadi penting untuk melihat bagaimana sosialisasi mengenai hukum kekayaan intelektual (materil dan formil) kepada masyarakat; khususnya tentang mekanisme penegakan hukum yang dapat diakses oleh pengemban hak. Sosialisasi seyogyanya dalam konteks ini dipandang sebagai prakondisi efektivitas penegakan hukum oleh PPNS. ${ }^{43}$ Hal ini terbukti dengan minimnya aduan pidana KI kepada Kanwil Hukum dan HAM, yang justru dialamatkan kepada kepolisian atau Ditjen KI di tingkat pusat. Dengan demikian, berdasarkan analisis di atas dapat dipahami bahwa penegakan hukum, baik dari segi internal maupun eksternal, belum

Surat Kapolri No Pol: B/3022/XII/2009/SDEOPS tanggal 14 Desember 2009 tentang Penanganan Kasus Melalui AlternatifDispute Resolution. Lihat Edy Herdiyanto, Achmad, Zakki Adlhiyati, Kebijakan Mediasi Penal pada Kasus Pencurian di Kepolisian Surakarta, MMH 42 No. 2 , April 2013, hlm. 244-250.

42 Wawancara dengan Informan di Reserse Kriminal Khusus Polda Bali, pada 13 September 2017.

43 Henry Soelistyo, "Potret HaKI di Era Globalisasi", http://haki.lipi.go.id/utama.cgi?artikel\&1101524828\&2, diakses 02 Oktober 2017. Anis Mashdurohatun, "Problematika Perlindungan Hak Cipta di Indonesia", Yustisia Vol.1, No.1 Januari - April 2012. hlm 71-89. 
menunjukkan kerangka pengorganisasian PPNS yang efektif dan efisien.

\section{Kesimpulan}

Efektivitas penegakan hukum kekayaan intelektual oleh PPNS KI di lingkungan Kementerian Hukum dan HAM dipengaruhi oleh pelbagai kondisi, yang secara teoretik dapat dipilah ke dalam dua elemen, yakni internal dan eksternal. Berdasarkan data lapangan serta analisis yang dilakukan, kajian ini menyimpulkan beberapa hal terkait efektivitas penegakan hukum kekayaan intelektual oleh PPNS: Pertama, secara internal PPNS KI, baik yang bertugas di Direktorat Jenderal Kekayaan Intelektual maupun di Kantor Wilayah lokus kajian, pada prinsipnya sudah berupaya untuk menjalankan fungsinya secara efektif, walaupun belum berada pada kondisi yang ideal. Beberapa faktor internal yang menjadi kendala kinerja penyidikan kekayaan intelektual oleh PPNS meliputi: (i) belum terdapat struktur PPNS KI di Kantor Wilayah, dan (ii) penempatan dan pengangkatan jabatan seorang PPNS KI ke dalam jabatan atau posisi tertentu, baik di tingkat pusat maupun wilayah, yang tidak relevan dengan tugas dan wewenang sebagai PPNS.

Kedua, secara eksternal berdasarkan tinjauan regulasi yang ada, dapat dipahami bahwa mekanisme penegakan hukum kekayaan intelektual dapat dijalankan dengan beberapa jalur. Untuk itu, dapat dipahami bahwa kuantitas tindak pidana yang disidik oleh PPNS KI tidak dapat secara serta merta dianggap sebagai parameter efektivitas dari sisi regulasi. Di sisi lain, kondisi ketidakmutlakan penyelesaian perkara pidana kekayaan intelektual melalui jalur litigasi ini dianggap akan mendukung fungsi hukum pidana sebagai ultimum remidium. Dengan demikian, normativitas kewenangan PPNS yang tidak mencakup ranah mediasi penal menyebabkan kewenangan mereka menjadi sangat terbatas. Selain itu, dinamika perkembangan norma hukum pidana juga memengaruhi efektivitas kinerja PPNS. Hal ini ditandai dengan terbitnya Putusan Mahkamah Konstitusi yang menghapus ketentuan beberapa pasal di KUHAP, yang menuntut PPNS KI untuk lebih tanggap dalam proses penegakan hukum.

Beranjak dari kesimpulan tersebut, tulisan ini merumuskan beberapa rekomendasi kebijakan dalam rangka mendorong efekvitias penegakan hukum kekayaan intelektual oleh PPNS sebagai berikut: Pertama, Kepada Direktorat Jenderal Kekayaan Intelektual untukperlu melakukan 4 (empat) hal, yakni: (1) Menambahkan wewenang PPNS KI untuk mencakup proses mediasi penal penyelesaian sengketa kekayaan intelektual. Hal ini dapat dilakukan dengan mendorongperubahanundang-undangkekayaan intelektual yang berlaku saat ini, khususnya terkait wewenang PPNS KI. Rekomendasi ini dirumuskan dengan mengingat bahwa mekanisme penegakan hukum berdasarkan undang-undang kekayaan intelektual yang ada mengadopsi model kuasi perdata-pidana; (2) Sejalan dengan rekomendasi tersebut, maka diperlukan perubahan kerangka normatif penegakan hukum kekayaan intelektual dengan mempertegas posisi mekanisme mediasi-penal di dalam undang-undang sektoral kekayaan intelektual. ${ }^{44}$ Hal ini diharapkan akan sejalan dengan pembaruan hukum pidana yang berupaya mengatasi kekakuan/formalitas dalam sistem yang berlaku; ${ }^{45}$ (3) Meningkatkan koordinasi internal antara pusat dengan wilayah

44 Secara teknis, beberapa model mediasi penal yang dapat dirujuk mencakup: informal mediation, traditional village or tribal moots, victimoffender mediation, reparation negotiation programmes, community panels or courts, family and community group conferences. Lihat Committee of Ministers of the Council of Europe, Recommendation No. R (99) 19 Mediation in Penal Matters, adopted on 15 September 1999.

45 Lihat Barda Nawawi Arief, Kebijakan Legislatif dalam Penanggulangan Kejahatan dengan Pidana Penjara, Semarang (2000), BP UNDIP. Selain itu, gagasan ini juga akan sejalan dengan pengaturan mediasi penal di dalam Rancangan Kitab Undang-Undang Hukum Acara Pidana. 
yang diarahkan pada peningkatan kompetensi, serta fasilitasi akses informasi yang seluasluasnya kepada PPNS KI di seluruh wilayah mengenai produk-produk hukum yang sudah diterbitkan di tingkat Ditjen KI (misalnya terkait data registrasi kekayaan intelektual). Selain itu, upaya koordinasi dengan aparat penegak hukum negara lain juga menjadi penting, mengingat kemajuan teknologi informasi yang berkontribusi terhadap terjadinya tindak pidana kekayaan intelektual; ${ }^{46}$ dan (4) Meningkatkan eksistensi PPNS KI di tengah masyarakat dengan melakukan sosialisasi mekanisme penegakan hukum kekayaan intelektual kepada masyarakat sebagai solusi jangka pendek.

Kedua, kepada Direktur Jenderal Administrasi Hukum Umum, Kementerian Hukum dan Hak Asasi Manusia perlu meningkatkan kapasitas PPNS KI melalui program-program peningkatan kompetensi penyidik, khususnya yang berkaitan dengan dinamika dan fenomena norma hukum yang berlaku, serta putusan pengadilan, seperti Mahkamah Konstitusi, yang relevan dengan fungsi penyidikan. Ketiga, kepada Sekretaris Jenderal Kementerian Hukum dan Hak Asasi Manusia dan Direktur Jenderal Kekayaan Intelektual perlu mempertimbangkan untuk memberikan insentif khusus kepada pejabat PPNS KI, baik yang berada di Ditjen KI maupun Kantor Wilayah, agar meningkatkan daya tawar jabatan tersebut dalam pembinaan karier pegawai. Insentif yang dilakukan dapat berupa: (i) tunjangan khusus bagi para PPNS, dan (ii) pengangkatan PPNS KI sebagai jabatan fungsional. Pilihan kebijakan ini diharapkan mampu meningkatkan motivasi internal para personel PPNS KI yang ada.

\section{DAFTAR PUSTAKA}

\section{A. Buku}

Arief, Barda Nawawi, 2000, "Kebijakan Legislatif dalam Penanggulangan Kejahatan dengan Pidana Penjara”, BP UNDIP, Semarang.

Blakeney, Michael, tanpa tahun, Guidebook on Enforcement of Intellectual Property Rights, Queen Mary Intellectual Property Research Institute, Queen Mary, University of London.

Harahap, M. Yahya, 2006, Pembahasan Permasalahan dan Penerapan KUHAP: Penyidikan dan Penuntutan, Sinar Grafika, Jakarta.

Tresna, R., 1959, Azas-azas Hukum Pidana Disertai Pembahasan Beberapa Perbuatan Pidana yang Penting, Tiara, Jakarta.

\section{B. Artikel Jurnal}

Buccafusco, Christoper, et al., "Innovation and Incarceration: An Economic Analysis of Criminal Intellectual Property Law", Southern California Law Review, 87, 2014.

DuBose, Michael M., "Criminal Enforcement of Intellectual Property Law in the Twenty-First Century”, 29 Colum. J.L. \& Arts 481, 20052006.

Herdiyanto, Edy. Achmad, Zakki Adlhiyati, "Kebijakan Mediasi Penal pada Kasus Pencurian di Kepolisian Surakarta”, Masalah Masalah Hukum, Vol. 42 No. 2, April 2013.

Kilmann, Ralph H dan Richard P. Herden, "Towards a Systemic Methodology for Evaluating the Impact of Inteventions on Organizational Effectiveness", Academy of Management Review, Juli 1976.

Lanjouw, Jean O. \& Josh Lerner, "The Enforcement of Intellectual Property Rights: A Survey of the Empirical Literature", Working Paper 6296 National Bureau of Economic Research,

\footnotetext{
46 Michael M. DuBose, 2006, Criminal Enforcement of Intellectual Property Law in the Twenty-First Century, 29 Colum. J.L. \& Arts 481 (2006), hlm. 494-495.
} 
December, 1997.

Manta, Irina D, "The Puzzle Sanctions for Intellectual Property Infringement", Harvard Journal of Law \& Technology, Vol. 24 No. 2 Spring 2011.

Mulyadi, Lilik, "Mediasi Penal dalam Sistem Peradilan Pidana Indonesia: Pengkajian Asas, Norma, Teori dan Praktik", Yustisia, Vol.2 No.1 Januari - April 2013.

Raharjo, Agus, "Mediasi sebagai Basis dalam Penyelesaian Perkara Pidana", Mimbar Hukum, Vol. 20, No. 1, Februari 2008.

Wibowo, Ari, "Justifikasi Hukum Pidana terhadap Kebijakan Kriminalisasi Pelanggaran Hak Cipta, serta Perumusan Kualifikasi Yuridis dan Jenis Deliknya", Jurnal Hukum Ius Quia Iustum, Vol. 22, No. 1, Januari 2015.

\section{Internet}

Henry Soelistyo, "Potret HaKI di Era Globalisasi”, http://haki.lipi.go.id/utama. cgi?artikel\&1101524828\&2, diakses 02 Oktober 2017.

\section{Peraturan Perundang-undangan}

Peraturan Pemerintah Nomor 43 Tahun 2012 tentang Tata Cara Pelaksanaan Koordinasi, Pengawasan, dan Pembinaan Teknis terhadap Kepolisian Khusus, Penyidik Pegawai Negeri Sipil, dan Bentuk-bentuk Pengamanan Swakarsa (Lembaran Negara Republik Indonesia Tahun 2012 Nomor 74, Tambahan Lembaran Negara Republik Indonesia Nomor 5298).

Peraturan Menteri Hukum dan HAM Nomor 29 Tahun 2015 tentang Organisasi dan Tata Kerja Kementerian Hukum dan HAM.

Peraturan Kepala Kepolisian Negara Nomor 6 Tahun 2010 tentang Manajemen Penyidikan oleh Penyidik Pegawai Negeri Sipil (Berita Negara Republik Indonesia Tahun 2010
Nomor 118).

Keputusan Menteri Hukum dan HAM No. M.HH01.H1.07.02 Tahun 2015 tentang Petunjuk Pelaksanaan Manajemen Penydikan Tindak Pidana di Bidang Kekayaan Intelektual.

\section{E. Putusan Pengadilan}

Putusan Mahkamah Konstitusi Nomor 130/PUUXIII/2015 perihal Pengujian Undang-Undang Nomor 8 Tahun 1981 tentang Hukum Acara Pidana terhadap Undang-Undang Dasar Negara Republik Indonesia Tahun 1945, 11 Januari 2017.

Putusan Mahkamah Agung No. 332 K/PID. SUS/2013.

Putusan Mahkamah Agung No. 1010 K/Pid. Sus/2013.

Putusan Pengadilan Negeri Bukittinggi No. 74/ PID.B /2013 /PN.BT

Putusan Pengadilan Negeri Kediri No. 180/Pid. Sus/2013/N.Kdi.

Putusan Pengadilan Negeri Kediri No. 181/ Pid.Sus / 2013 / PN. Kdi

Putusan Pengadilan Negeri Jakarta Pusat No. 2368/ PID.B/2007/PN.JKT.PST

Putusan Pengadilan Negeri Jakarta Pusat No. 1778/ Pid.B/2011/PN.JKT.PST

Putusan Pengadilan Negeri Jakarta Pusat No. 1781/ Pid.Sus/2013/PN.Jkt.Pst.

Putusan Pengadilan Negeri Jakarta Pusat No. 579/ PID.B/2013/PN.JKT.PST.

Putusan Pengadilan Tiggi DKI Jakarta No. 72/ PID/2014/PT.DKI.

Putusan PN Surakarta No. 75/Pid.Sus/2015/PN Skt..

Putusan PN Surakarta No. 80/Pid.Sus/2015/PN Skt.

\section{F. Dokumen Internasional}

Committee of Ministers of the Council of Europe, Recommendation No. R (99) 19 Mediation in Penal Matters, adopted on 15 September 1999. 
Office of the United States Trade Representative, Special 301 Report, 2016.

Office of the United States Trade Representative, Special 301 Report, 2017.
G. Dokumen Lain

Data administrasi penyidikan, Direktorat Penyidikan dan Penyelesaian Sengketa Direktorat Jenderal Kekayaan Intelektual Kementerian Hukum dan HAM RI Tahun 2015-2017. 